\title{
MAZHAB SYAFI'I DALAM PENGAJIAN SYARIAH DI MALAYSIA: SATU ANALISIS
}

\author{
Oleh: \\ Rahimin Affandi Abdul Rahim* \\ Mohd Anuar Ramli**
}

\begin{abstract}
Basically the paper attempts to investigate the reality and form of Shafi'ite School in Shariah studies in Malaysia. The discussion is divided into introduction, philosophy and views on practicing schools of fiqh, reality of Shafi ite school in Shariah studies in Malaysia from historical perspective which covers Shafi'ite in Shariah studies during the classical and post independence periods focusing on principal texts and references, methods as well as researches. The fourth part focuses on the future of Shariah studies in Malaysia while the final part summarizes the discussion.
\end{abstract}

\section{PENGENALAN}

Pengaruh dan impak dominasi fiqh yang terangkum di dalam pengajian Syariah boleh dilihat kepada tinggalan warisan

\footnotetext{
* Prof. Madya, Jabatan Fiqh \& Usul, Akademi Pengajian Islam, Universiti Malaya, Kuala Lumpur.

** Pengajar, Jabatan Fiqh \& Usul, Akademi Pengajian Islam, Universiti Malaya, Kuala Lumpur.
} 
perbendaharaan fiqh Islam yang cukup besar, ${ }^{1}$ sehingga mencetuskan penubuhan pelbagai mazhab dalam Islam. Salah satu daripada warisan mazhab fiqh yang cukup dominan adalah mazhab Syafi'i itu sendiri, yang masih diterima pakai secara rasmi oleh kebanyakan dunia umat Islam sekarang, termasuklah di rantau Nusantara, suatu kawasan terbesar yang memiliki penganut Islam. ${ }^{2}$ Berasaskan kepada latar belakang ini, kajian ini akan cuba meneliti beberapa elemen penting yang dikaitkan secara langsung dengan nisbah pengamalan mazhab Syafi'i dalam pengajian Syariah di Malaysia. Bagi tujuan pengkhususan, tumpuan utama akan diberikan kepada pengalaman APIUM, yang turut disertakan dengan beberapa IPTA/IPTS yang terpilih. Di akhir perbincangan, suatu cadangan alternatif diberikan bagi memastikan kelangsungan mazhab Syafi'i ini masih dikekalkan sama ada di dalam kehidupan seharian mahupun dalam sistem pengajian Syariah.

\section{FALSAFAH DAN PANDANGAN BERMAZHAB DI DALAM ISLAM}

Kewujudan mazhab hanya timbul pada akhir abad ketiga Hijrah. Namun begitu, benih ataupun asas awal dikesan telah timbul sejak daripada zaman awal Islam lagi, merangkumi zaman Rasulullah, Sahabat, Tàbi 'în, Tàbi 'Tābi 'în dan mujtahid muṭlaq. Dalam semua zaman yang awal ini, asas mazhab Islam sama ada dalam bidang fiqh, teologi dan politik ${ }^{3}$ sudahpun timbul, yang kemudiannya

Mohd Daud Bakar (1999), “ Hukum Islam Antara Prinsip Syariah Dan Perbendaharaan Fiqh ", dalam Abdul Karim Ali (ed.), Hukum Islam Semasa Bagi Masyarakat Malaysia Yang Membangun. Kuala Lumpur: APIUM, hh. 35-40.

2 Abdul Halim El-Muhammady (2001), Adab Berijtihad Dan Berikhtilaf Mengikut Syari'at. Kajang: IPI, hh. 12-13.

3 Sebagai contoh, perpecahan mazhab politik Sunni-Syiah di peringkat awal (zaman Rasulullah) boleh dilihat daripada pertelingkahan tentang pengganti Rasulullah. Ianya terbahagi kepada dua puak; pengikut fahaman Uthmaniyyah (pendukung sahabat) dan pengikut Ahl Bayt, yang kemudiannya melahirkan mazhab Sunni dan syiah. Lihat: S.H.M. Jafri (1979), The Origin And Early Development Of Shi'a Islam. London: Muhammady Trust, hh. 277-281. 
diperkukuhkan doktrinnya oleh penganut Islam di abad ketiga Hijrah. Maknanya, kewujudan setiap mazhab ini bukan datang daripada ruang yang kosong, tetapi berasaskan kepada latar belakang sosial, precedent silam ataupun buah pemikiran yang diletakkan asasnya oleh masyarakat dan sarjana Islam yang terdahulu. ${ }^{4}$ Selanjutnya, keabsahan, penerimaan dan dominasi sesuatu mazhab itu bergantung sepenuhnya dengan dukungan pemerintah semasa yang wujud dalam sejarah tamadun Islam. ${ }^{5}$

Secara kasarnya, mazhab merupakan paradigma ${ }^{6}$ berfikir masyarakat Islam mengikut world-view dan kaedah Syariah yang diasaskan oleh seseorang fuqaha tertentu. Ianya lahir daripada tradisi Islam sendiri dan bukannya berasal daripada pengaruh asing seperti didakwa oleh orientalis barat. ${ }^{7}$ Ianya merupakan kemuncak dari satu proses pembentukan world-view yang panjang. Worldview adalah pandangan dunia, hidup, kepercayaan dan pemikiran yang berfungsi sebagai pemangkin untuk segala perilaku manusia. ${ }^{8}$ Mengikut Hamid Zarkashi, world-view Islam adalah: "visi tentang realiti dan kebenaran, berupa kesatuan pemikiran

$4 \quad$ Aziz Azmeh (1989), "Islamic Legal Theory And Appropriation", dalam Aziz Azmeh (ed.), Islamic Law: Social And Historical Contexts. London: Routledge, hh. 250-251.

5 Rahimin Affandi Ab Rahim (1994), "Hubungan Antara Ulamak Dan Pemerintah Di Dalam Sejarah Tamadun Islam”, dalam Jurnal Pengajian Melayu, V. 4.

6 Paradigma adalah satu set proposisi (rancangan usulan) yang menerangkan bagaimana dunia harus difahami. Ia berisikan sebuah pandangan dunia (world-view), suatu cara untuk memecahkan kerumitan dunia, yang memberitahu seseorang ilmuan tentang apa yang penting, apa yang sah dan apa yang bersesuaian dengan logik. Lihat Mona Abdul-Fadl (1989), Paradigms In Political Science Revisited.Herndon: AMSS \& IIIT.

7 T.J. De Boer (1994), The History Of Philosophy In Islam. Richmond: Curson press, hh 28-29 \& 309.

8 Muhammad Abu Bakar (1993), "Pandangan Dunia, Ideologi Dan Kesarjanaan: Islam, Proses Sejarah Dan Rekonstruksi Realiti Sosial”, dalam Tinta Kenangan, Sumbangan Sempena Persaraan Dan Perlantikan Naib Canselor, Profesor Datuk Mohd Taib Osman. Kuala Lumpur, hh. 307-309. 
yang arsitektonik, yang berperanan sebagai asas yang tidak nampak (non-observable) bagi semua perilaku manusia, termasuk aktiviti ilmiah dan teknologi". Antara elemen asas untuk worldview Islam terdiri dari konsep tuhan, wahyu dan penciptaannya, psikologi manusia, ilmu, agama, kebebasan, nilai dan kebajikan dan kebahagiaan. Elemen-elemen inilah yang kemudiannya yang menentukan bentuk perubahan (change), perkembangan (development) dan kemajuan (progress) dalam Islam. ${ }^{9}$

Dalam konteks Malaysia semasa, terdapat dua persepsi khusus, negatif dan positif dalam soal bermazhab. Ianya terdiri daripada pertamanya golongan yang memandang negatif terhadap institusi mazhab. Golongan ini terbahagi kepada tiga jenis yang utama;

1. Penganut Wahhabisme; berpegang kepada paradigma;

- Mengamalkan " backward looking" dalam mengemukakan jawapan terhadap permasalahan umat Islam. Bagi mereka, umat Islam tidak dibenarkan berpegang kepada sesuatu mazhab khalaf, sebaliknya perlu berpegang kepada mazhab Salaf yang menjadi amalan penganut Islam yang awal, yang kononnya terbukti lebih suci pegangan keagamaannya berbanding dengan umat yang terkemudian. ${ }^{10}$

- Eksklusif (tertutup) yang tidak mahu menerima pandangan yang berasal daripada luar, lebih-lebih lagi dalam soal keagamaan. Bagi mereka, hanya pandangan kumpulan mereka sahaja yang paling betul dan menafikan hal ini kepada golongan lain, lebih-lebih lagi yang mempunyai kaitan dengan dunia Barat. ${ }^{11}$

- Mengamalkan pendekatan literalis dalam memahami ajaran Islam, tanpa merasa perlu melihat konteks sesuatu ayat Quran dan Sunnah itu diturunkan pada zaman Rasulullah. ${ }^{12}$

9 Hamid Fahmy Zarkasyi (2004), Tantangan Sekularisasi Dan Liberalisasi Di Dunia Islam. Surabaya: Penerbit Khairul Bayan, hh. 1-6.

10 Abu Bakar Hamzah (1981), Al-Imam: Its Role In Malay Society 1906-1908. Kuala Lumpur, hh. 54-55.

11 Ibrahim Abu Bakar (1994), Islamic Modernism In Malaya, Kuala Lumpur: Penerbit Universiti Malaya, hh. 14-16.

12 H. Abuddin Nata (2000), Peta Keragaman Pemikiran Islam Di Indonesia. Jakarta: Rajawali Pres, h. 143. 
2. Penganut fahaman sekularis, ${ }^{13}$ merangkumi Jemaah alQuran Malaysia ${ }^{14}$ dan Sisters in Islam. ${ }^{15}$ Golongan ini terlalu bergantung kepada kerangka paradigma barat dalam usaha memahami ajaran Islam. Antara lainnya sikap ini boleh diperincikan dengan;

- Kemunduran umat Islam dari segi fizikal dan intelektual berpunca daripada kesilapan metodologi Islam yang dibangunkan oleh sarjana Islam silam. Jemaah alQuran Malaysia secara terang-terangan mencabar autoriti sistem fiqh yang telah dibina oleh fuqaha silam. Dalam membuat tafsiran terhadap ajaran Islam, golongan ini lebih menggunakan kaedah yang longgar dan bertentangan dengan kaedah sarjana Islam silam. Mereka enggan menerima metode asas pengetahuan Islam dan prinsip yang ditetapkan oleh sarjana Islam silam, seperti $;{ }^{16}$

- Kepentingan mengetahui bahasa Arab untuk mendalami kandungan Quran dan Sunnah. Bagi golongan ini, pada masa sekarang, pemahaman terhadap ajaran Islam boleh dilakukan oleh sesiapa sahaja yang mampu memahami bahasa Inggeris, khususnya dengan membaca bahan rujukan ajaran Islam yang dihasilkan oleh sarjana barat.

- Menolak Hadis Rasulullah sebagai salah satu sumber hukum Islam yang berautoriti bagi memperincikan kandungan Quran. Hadis adalah ciptaan ulamak Islam pada abad ke dua Hijrah yang dinisbahkan kepada

13 Abdul Rahman Abdullah (1997), Pemikiran Islam Di Malaysia: Sejarah dan Aliran. Jakarta: Gema Insani.

14 Zulkifli Mohd (2002), Anti Sunnah Movement And It's Impact On The Muslim Ummah. Kuala Lumpur: Panawira Sdn Bhd, hh. 58-62.

15 Rahimin Affandi Abdul Rahim (2005), "Isu Dan Pengaruh Orientalisme di Malaysia: Satu Analisa”, dalam Jurnal 'Ulum Islamiyyah, v. 2, no. 1, hh. 11-42.

16 Rahimin Affandi Abdul Rahim (2006), "Islam Dan Isu Penterjemahan Dalam Era Globalisasi”, dalam Hamedi Mohd Adnan (ed.), Penerbitan Malaysia-Indonesia: Mengukuhkan Jaringan Penerbitan Serantau. Kuala Lumpur: Penerbit UM, hh. 151-164. 
Rasulullah sebagai cara untuk mendapatkan keabsahan autoritinya.

- Tindakan yang secara terang-terangan menghina peribadi Rasulullah, yang digambarkan sebagai seorang biasa dan mementingkan hawa nafsu dengan memiliki ramai isteri dan gundik. ${ }^{17}$

- Perjuangan Rasulullah bukannya berbentuk Risalah Kenabian seperti mana termasuk dalam rangkaian kenabian yang terdahulu, tetapi lebih berbentuk perjuangan kemanusiaan seperti tokoh-tokoh yang lain; perjuangan berasaskan Arabism (Tribal leader) yang bertujuan mengangkat martabat bangsa Arab berbanding dengan bangsa bukan Arab. ${ }^{18}$

- Sifat yang menyama tarafkan antara peribadi Rasulullah dengan tokoh lain, dengan tidak perlu menerima autoriti dan butiran pengajarannya yang terkandung dalam Sunnah Rasulullah. Sebaliknya, penganut Islam hanya perlu berpegang kepada sumber al-Quran sematamata. ${ }^{19}$

- Tindakan yang menyebarkan sikap dan pendekatan mungkar barat yang menganggap biasa pandangan yang menghina diri Rasulullah dan tokoh agama, yang kononnya bersesuaian dengan konsep kebebasan bersuara dan mengeluarkan pendapat yang amat ditekankan oleh pemikiran demokrasi moden. Akibatnya, anggota masyarakat termasuklah penganut Islam akan mengamalkan "sikap tidak apa" terhadap tindakan

17 Farish A. Noor (2000), "Let Islam lead the way with its progressive view on sexuality", dalam News Strait Times, 4 November 2000.

18 Farish A. Noor (2001), " The Myth Surrounding The Islamic State”, dalam News Strait Times, 1 Disember 2001.

19 Mohd. Napiah Abdullah (2006), "Penolakan Hadith Oleh Orientalis Dan Penulis Islam”, dalam Islam Dalam Persepsi Orientalisme, Terbitan Tak berkala no. 3, Jabatan Usuluddin dan Falsafah, Fakulti Pengajian Islam, UKM, Bangi, hh. 41-44. 
yang mengutuk Rasulullah, seperti mana berlaku secara berleluasa dalam masyarakat barat. ${ }^{20}$

- Imam Syafi‘i adalah orang utama yang perlu dipersalahkan kerana beliau merupakan orang pertama yang mengemukakan teori hadis sebagai autoriti pegagan selepas Quran dan mengasaskan kerangka ilmu Usul Fiqh yang perlu dipakai untuk membangunkan sistem fiqh Islam.

- Pemimpin umat Islam perlu menjalankan dasar pemerintahan mengikut kesesuaian dengan realiti tempatan tanpa perlu terikat dan mengikut apa yang dijalankan oleh Rasulullah melalui sunahnya.

- Semua taklif syarak yang difardukan kepada umat Islam bukan bersumberkan kepada autoriti hadis, tetapi semuanya pada hakikatnya telah diwariskan sejak zaman Nabi Allah Ibrahim lagi.

- Hadis hanya akan menyebabkan umat Islam menjadi fanatik dan tidak bersifat intelektual, memandangkan hadis itu sendiri bertentangan dengan Quran, sains dan sejarah kemanusiaan.

- Banyak daripada ajaran Islam samada dalam bidang Syariah dan teologi sudah tidak relevan, ketinggalan zaman dan tidak sesuai dipakai lagi untuk konteks zaman moden ini.

- Proses pembaharuan yang perlu diterapkan dalam memperbaiki kelemahan umat Islam perlu menggunakan pendekatan reform ala barat, yang perlu menolak semua asas dan pemahaman Islam silam, dan sebagai gantinya umat Islam perlu bergantung kepada pendekatan baru seperti mana dikemukakan oleh dunia barat.

Tidak keterlaluan jika dikatakan bahawa impak gerakan anti hadis ini amat besar kepada kelangsungan umat Islam. Hal ini telah disedari dengan cukup jelas oleh kalangan sarjana

20 Wan Mohd Nor Wan Daud (2001), Pembangunan Di Malaysia: Ke Arah Suatu Kefahaman Baru Yang Lebih Sempurna. Kuala Lumpur: ISTAC, h. 3. 
Islam di Malaysia, yang telah bertungkus lumus mengkritik dan mendedahkan kesilapan besar yang terkandung dalam ajaran gerakan ini. Walaupun momentum gerakan anti hadis ini kelihatannya telah mula berkurangan, tetapi sebenarnya gerakan ini telah mendapat dukungan kuat dari pelbagai kalangan masyarakat atasan di Malaysia, khususnya dalam kalangan sekularis.

3. Penganut fahaman Liberalis, berasal daripada Indonesia, yang menyebarkan fahaman mereka kepada penganut Islam di Malaysia. Walaupun pengaruh fahaman ini belum mendapat dukungan kuat daripada penganut Islam di Malaysia, terdapat kebimbangan sesetengah pihak bahawa ianya akan turut dipegang oleh penganut Islam di Malaysia, berasaskan kepada sumber pemikiran golongan ini yang amat mudah diperolehi melalui buku import dan internet. Paradigma golongan ini lebih berupa penggunaan alat analisis terhadap permasalahan umat Islam semasa, yang secara terang-terangan mencabar metodologi sarjana Islam silam (pandangan bermazhab) dan terpengaruh dengan metodologi barat era pasca-kolonialisme (era globalisasi);

- Isu penentangan terhadap pendekatan teokrasi, pemusatan kuasa pemerintahan negara kepada golongan ulamak semata-mata. ${ }^{21}$

- Isu Islam emansipatoris - Islam patut digunakan untuk membela masyarakat bawahan yang tertindas oleh pihak pemerintah. ${ }^{22}$

- Isu penentangan terhadap fahaman ortodoksi yang kononnya menegaskan bahawa golongan ulamak-pemerintah yang menguasai dan memonopoli pentafsiran Islam yang sejati. ${ }^{23}$

21 Amin Abdullah (2004), Studi Agama: Normativitas Atau Historisitas. Yogyakarta: Pustaka Pelajar.

22 Mahsun Fuad (2005), Hukum Islam Indonesia: Dari Nalar Partisipatoris Hingga Emansipatoris. Yogyakarta: LKIS; Masdar Farid Mas'udi (1991), Agama Keadilan: Risalah Zakat Dalam Islam. Jakarta: P3M.

23 Abdul Hadi W.M. (2001), Tasawuf Yang Tertindas: Kajian Hermeneutic Terhadap Karya-Karya Hamzah Fansuri. Jakarta: Penerbit Paramadina; Marzuki Wahid (2001), Fiqh Mazhab Negara: Kritik Atas Politik Hukum Islam Di Indonesia. Yogyakarta: LKIS. 
- Isu teologi pembaharuan - kepentingan mewujudkan fahaman tajdid Islam baru yang gagal disentuh secara tuntas oleh ulamak Islam silam. ${ }^{24}$

- Isu cabaran terhadap tafsiran ulamak silam, khususnya dalam bidang tafsir Quran. ${ }^{25}$

- Isu pluralisme agama, yang menganggap semua agama adalah sama di sisi tuhan dan boleh membawa kesejahteraan kepada umat manusia. ${ }^{26}$

- Isu penggunaan metodologi dekonstruksi dan rekonstruksi terhadap semua ajaran Islam silam. ${ }^{27}$

- Isu penentangan terhadap doktrin taqlid dan ijtihad. ${ }^{28}$

24 Fauzan Salleh (2001), Teologi Pembaruan: Pergeseran Wacana Islam Sunni Di Indonesia Abad XX, Jakarta: PT Serambi Ilmu Semesta.

25 Sebagai Maklumat Lanjut Sila Baca Khaled M. Abou El-Fadl (2001), Atas Nama Tuhan: Dari Fikih Otoriter Ke Fikih Otoritatif, R. Cecep Lukman Yasin (terj.). Jakarta: PT Serambi Ilmu Semesta; Muhammad 'Ata Al-Sid (2004), Sejarah Kalam Tuhan : Kaum Beriman Menalar Al-Quran Masa Nabi, Klasik Dan Modern, Ilham B. Saenong (terj.). Jakarta: Khazanah Pustaka Keilmuan; Sahiron Syamsuddin (2003), Hermeneutika Al-Quran: Mazhab Yogya. Yogyakarta: Penerbit Islamika.

26 Budhy Munawar Rachman (2002), Islam Pluralis : Wacana Keset raan Kaum Beriman, Jakarta : Penerbit Paramadina.

27 Ilyas Supena (2002), Dekonstruksi Dan Rekonstruksi Hukum Islam. Yogyakarta: Gama Media, hh. 80-96.

28 Amin Abdullah (2000), “Kajian Ilmu Kalam di IAIN: Menyongsong Perguliran Paradigma Keilmuan Keislaman Pada Era Milenium Ketiga”, dalam Al-Jamiah, No. 65/VI/2000; Amir Mualim (2004), Ijtihad Dan Legislasi Muslim Kontemporer. Yogyakarta: UII Press; Sahal Mahfudh (1994), Nuansa Fiqh Social. Yogyakarta: LKIS; Riyanto (2004), Neo Usul Fiqh : Menuju Ijtihad Kontekstual. Yogyakarta: Fakultas Syariah Press. 
- Isu pertentangan warisan ulamak Islam silam dengan pengetahuan S\&T. ${ }^{29}$

- Isu yang membenarkan perkahwinan kahwin antara penganut Islam dan bukan Islam. ${ }^{30}$

Bertentangan dengan golongan di atas, masih terdapat dalam kalangan penganut Islam di Malaysia yang mengamalkan sikap positif dan selektif terhadap amalan bermazhab. Golongan ini kebanyakannya terdiri daripada kalangan ahli akademik dan pihak autoriti agama. ${ }^{31}$ Golongan ini berpendapat amalan bermazhab dibolehkan kerana beberapa faktor yang utama;

1. Ianya menetapkan ulamak sebagai pentafsir utama kepada ajaran agama. Hal ini boleh dirujuk sebagai contohnya kepada keabsahan konsep taqlid dan ijtihad. Dalam konsep taqlid, ianya mengharuskan masyarakat awam untuk bertaqlid kepada seseorang mujtahid, berasaskan kepada nisbah ketidakmampuan seseorang awam untuk memahami ajaran agama Islam secara mendalam. ${ }^{32}$ Sikap yang hanya bergantung sepenuhnya kepada prinsip taqlid ini kemudiannya cuba dibataskan dengan penerimaan kepada konsep ijtihad dan tajdid.

2. Pendekatan ini ditetapkan bukannya bertujuan untuk memonopolikan usaha pentafsiran agama kepada golongan ulamak semata-mata, tetapi ianya dibuat bagi mengelakkan

29 Kamaruzzaman Bustaman Ahmad (2002), Islam Historis; Dinamika Studi Islam Di Indonesia. Yogyakarta: Galang Press; A. Khudori Soleh (2004), Wacana Baru Filsafat Islam. Yogyakarta: Pustaka Pelajar.

30 Tim Penulis Paramadina (2004), Fiqh Lintas Agama: Membangun Masyarakat Inklusif-Pluralis. Jakarta: Yayasan Wakaf Paramadina; Suhadi (2006), Kawin Lintas Agama: Perspektif Kritik Nalar Islam. Yogyakarta: LKIS.

31 Rahimin Affandi Abdul Rahim \& Noor Naemah Abdul Rahman (2005), "Pemikiran Reformasi Melayu Semasa: Satu Analisis", dalam Hashim Musa (ed.), Bahasa Dan Pemikiran Melayu. Kuala Lumpur: APMUM, hh. 332-265.

32 Rahimin Affandi Abdul Rahim (1993), “The Concept Of Ijma' In Islamic Law: A Comparative", dalam The Journal Of Hamdard Islamicus, Pakistan, v. 16, hh. 91-104. 
sebarang tindakan rakus daripada masyarakat awam yang jahil tentang prinsip asas Islam, melakukan tafsiran melulu dan boleh merosakkan nama baik Islam itu sendiri.

3. Faktor perpaduan dan keseragaman diperlukan bagi memastikan wujudnya kestabilan hidup sosio-politik umat Islam. Hal ini kemudiannya bakal memudahkan proses penguatkuasaan dan pentadbiran undang-undang Islam dijalankan. ${ }^{33} \mathrm{Hal}$ ini boleh dikatakan sebagai asas perpaduan umat Melayu sehingga tidak wujudnya perbalahan dan fanatik mazhab yang menimbulkan pertumpahan darah seperti mana berlaku di tempat-tempat lain. Cumanya, penekanan yang agak keterlaluan terhadap dominasi taqlid yang agak ketat ini dilihat bakal membuahkan hasil yang kurang sihat kepada perkembangan pemikiran hukum Islam itu sendiri. ${ }^{34} \mathrm{Hal}$ ini kemudiannya turut disedari sendiri oleh para mufti di Malaysia yang disertakan pula dengan pelbagai usaha untuk menerapkan pendekatan reformisme bagi menghadkan penggunaan taqlid secara berlebihan, khususnya dalam metodologi pengeluaran sesuatu fatwa. ${ }^{35}$

4. Sikap pro mazhab ini bukan bermakna kita perlu terjebak dengan fenomena fanatik mazhab yang boleh menyumbang kepada ketertutupan minda, tetapi perlu berpegang kepada kerangka metodologi (manhaj) ușuli sesuatu mazhab yang dilihat terbukti mampu menyelesaikan masalah hukum umat Islam. Kita tidak boleh memandang institusi taqlid ini secara negatif keseluruhannya, memandangkan mengikut persepktif tajdid yang tertanam di dalam hukum Islam itu sendiri, pelbagai perubahan yang diperlukan masih

33 Abdul Halim El-Muhammady (1992), "Ikhtilaf And Its Development In Malaysia", dalam International Islamic University Law Journal, v. 2, no.2, hh. $54-55 \& 57$.

34 Yusuf Qardawi (2004), Sanggahan Salah Tafsiran Islam, Abdul Rahman Rukaini (terj.). Kajang: Synergymate Sdn. Bhd, hh. 85-88.

35 Naemah Abd Rahman (2003), "Fatwa Jemaah Ulamak Kelantan Tahun 1920an Hingga 1990an: Satu Analisis", Tesis PhD, Jabatan Fiqh dan Usul, APIUM, hh. 183-185. 
dibolehkan bagi menunjukkan sifat dinamisme Syariah itu sendiri berhadapan dengan keperluan masyarakat. ${ }^{36}$

5. Berasaskan kepada adab keilmuan Islam, kita perlu mengakui sumbangan positif yang pernah dimainkan oleh fuqaha pelbagai mazhab dalam pembangunan keilmuan Islam. Hal ini bertepatan dengan pendekatan hormat-kritis terhadap pandangan sarjana sebelumnya yang terangkum di dalam konsep budaya ilmu. ${ }^{37}$

6. Kita perlu mengamalkan sikap selektif terhadap pemikiran barat yang kerap menisbahkan penerimaan amalan bermazhab ini dengan istilah tradisionalisme, suatu nisbah yang hina. Pandangan sebegini agak keterlaluan dan salah, jika dilihat dari persepktif yang lebih luas dan holistik. Paparan negatif ini sepatutnya tidak diterima secara melulu dan perlu dinilai secara berhikmah. ${ }^{38}$ Bagi penganut Islam, kita tidak boleh menganggap istilah tradisi membawa nisbah negatif seperti difahami dalam dunia akademik barat. Sebaliknya, istilah tradisionalisme ini yang bertapis perlu dibanggakan kerana tradisi merujuk kepada pemahaman dan penghayatan wahyu Allah di dalam kehidupan yang mencakupi tiga aspek; ${ }^{39}$ i) al-Din, agama sebagai panduan untuk keseluruhan aspek kehidupan membabit tiga bentuk hubungan, dengan Allah, mahkluk dan alam; ii)Sunnah, amalan yang terbentuk dan berkembang berdasarkan model sakral (berasaskan wahyu) sehingga menjadi amalan kebudayaan masyarakat yang berpanjangan dan iii) Salsilah, mata rantai yang menghubungkan setiap zaman dan pemikiran kepada asasnya yang utama, wahyu Allah.

36 Amir Mualim (2006), Ijtihad Dan Legislasi Muslim Kontemporer. Yogyakarta: UII Press, hh. ix-xiii.

37 Wan Mohd Nor Wan Daud (1990), "Budaya Ilmu Sebagai Asas Pembangunan Tamadun", dalam Jurnal Pendidikan Islam, v. 3, bil. 1, hh. 51-67.

38 Lihat Rahimin Affandi Abd. Rahim (2000), "Etika Penyelidikan Islam: Satu Analisa", dalam Jurnal AFKAR, bil. 1, hh. 190-191.

39 S. Hossein Nasr (1990), Traditional Islam In The Modern World. London: Kegan Paul International, hh. 13. 
Mengikut pandangan Islam, tidak semua perkara tradisi ataupun amalan lama dianggap sebagai buruk dan ketinggalan zaman. ${ }^{40}$ Begitu juga halnya dengan penumpuan matlamat dan komitmen yang kuat untuk berpegang dengan warisan tradisi Islam yang murni tidak boleh dianggap sebagai tindakan yang taksub dan fanatik. ${ }^{41}$ Kedua-dua perkara ini dalam kerangka barat telah dianggap sebagai buruk dan ketinggalan zaman, yang menetapkan semua perkara elemen baru, perubahan dan usaha meninggalkan amalan tradisi dianggap sebagai baik dan moden.

\section{REALITI MAZHAB SYAFI'I DALAM PENGAJIAN SYARIAH DI MALAYSIA}

Untuk mendapatkan gambaran yang jelas tentang pengajian Syariah di zaman moden, tidak dapat tidak kita perlu meneliti menggunakan persepsi sejarah, bagi mengetahui kenapa pengamalan mazhab Syafi'i begitu kukuh dominasi di dalam pengajian syariah era selepas Malaysia merdeka.

\section{Mazhab Syafi'i Dalam Pengajian Syariah Di Zaman Tradisi Klasik Alam Melayu}

Seperti mana direkodkan dalam catatan sejarah, walaupun kedatangan mazhab Syafi 'i di Alam Melayu agak lewat berbanding dengan mazhab Syiah, namun kemudiannya mazhab ini telah mampu mengatasi mazhab Syiah dan meninggalkan pelbagai elemen positif jangka panjang kepada masyarakat Alam Melayu. Hal ini berlaku kerana beberapa faktor utama;

1. Sifat mazhab Syafi'i yang berupa paradigma sintesis di antara pandangan Ahl Ray' dan ahli hadis. Ianya lebih adaptif dengan budaya tempatan Melayu. Mubaligh Syafi' $i$ yang awal telah mengamalkan sikap mesra budaya yang mendapat dukungan penguasa politik serta kemudiannya

40 Wan Mohd Nor Wan Daud (2001), Pembangunan Di Malaysia : Ke Arah Suatu Kefahaman Baru Yang Lebih Sempurna. Kuala Lumpur, hh. 12-17.

41 Lihat Mohamad Noor Habibi Long (2003), "Ekstremisme: Satu Perspektif", dalam Jurnal YADIM, bil. 5, hh. 114-118. 
mampu menyebarkan ajaran Islam secara cukup berkesan di Alam Melayu.$^{42} \mathrm{Hal}$ ini boleh dilihat di dalam Legal Digest Melayu seperti Hukum Kanun Melayu dan penyerapan nilai-nilai Islam di dalam sistem adat Melayu sehingga melahirkan ungkapan Adat bersendikan Hukum, hukum bersendikan Kitabullah. ${ }^{43}$

2. Gabungan antara paradigma sufi dan fiqh (neo-sufism) di dalam mazhab Syafi' $i$ - memberi kesan langsung kepada kepesatan proses pengislaman masyarakat Alam Melayu. ${ }^{44}$ Tidak seperti mazhab selain Syafi'i yang mengamalkan sikap negatif terhadap paradigma sufi, pendekatan ini tidak kedapatan dalam sejarah Alam Melayu.

3. Fuqaha mazhab Syafi'i telah mengasaskan sistem pendidikan Islam yang lebih sistematik di rantau Alam Melayu. ${ }^{45} \mathrm{Hal}$ ini merujuk kepada pengenalan sistem pondok yang mengandungi pasarana fizikal yang khusus, falsafah pengajian, struktur organisasi, susunan jadual waktu, kurikulum dan kaedah penilaian yang cukup sistematik. ${ }^{46}$

Merujuk khusus kepada kaedah pengajian syariah di zaman awal ini, kita dapat mengesan beberapa pendekatan yang digunakan;

1. Sistem pengajian Syariah lebih bermatlamatkan proses transmisi ilmu fiqh bagi pengamalan masyarakat harian,

42 Rahimin Affandi Abd. Rahim (2006), "Ulamak Dan Paradigma Menanggani Kebudayaan Melayu”, dalam Hashim Awang (ed.), Othman Yatim Dan Nor Azita Che Din (2006), Wacana Budaya. Kuala Lumpur: APMUM, hh. 55-80.

43 Siddiq Fadhil (2006), "Pertembungan Islam Dengan Budaya Peribumi: Pengalaman Alam Melayu", dalam Md Salleh Haji Ahmad (ed.), Hukum Islam Dan Budaya Tempatan. Kuala Lumpur: Jabatan Fiqh Dan Usul, APIUM, hh. 142-145.

44 A.H. John (1961), "Muslim Mystics And Historical Writing”, dalam Historians Of South-East Asia. London, hh. 40-41.

45 Abdul Latif Hamindong (1993), "Institusi Pondok Dalam Tradisi Budaya Ilmu”, dalam Tamadun Melayu. Kuala Lumpur, v. 2, h. 748.

46 Abdullah Ishak (1995), Pendidikan Islam Dan Pengaruhnya Di Malaysia. Kuala Lumpur: Dewan Bahasa \& Pustaka, hh. 212-218; 
dan bukannya untuk memperkembangkan lagi metodologi ilmu tersebut bagi menghadapi cabaran pemodenan. ${ }^{47}$

2. Manhāj usūlìyang dipakai adalah berasaskan kepada warisan zaman Taqlid daripada mazhab Syafi' $i$ yang tidak merujuk secara langsung kepada sumber asasi (Quran dan Sunnah) ataupun manhāj usūli mazhab Syafi'‘i. Sebaliknya tumpuan lebih diberikan kepada karya mazhab semata-mata. Karya ini telah dijadikan sumber ataupun bahan utama pengajaran dalam sistem pengajian Syariah. ${ }^{48}$

3. Pemakaian metodologi penulisan karya fiqh (kitab Jawi) yang sederhana bersesuaian dengan metodologi taqlid. ${ }^{49}$ Antara metodologi yang dimaksudkan adalah :-

- Penulisan karya fiqh (kitab jawi) lebih merupakan saduran dan terjemahan dari kitab asal zaman taqlid. ${ }^{50}$ Namun begitu, pemilihan yang rapi telah dibuat berasaskan kepada kitab-kitab yang berautoriti dan muktabar yang terkenal dalam dunia sunni pada masa itu. $^{51}$

- Kitab jawi telah menggunakan kitab turath era taqlid yang lebih awal sebagai sumber rujukan utama dan

47 Azyumardi Azra (1998), Esei-esei Intelektual Muslim Dan Pendidikan Islam. Jakarta, hh. 81-89.

48 Abdullah Alwi Haji Hassan (2003), Pengajian Dan Pengamalan Undang-Undang Islam Di Malaysia: Antara Tradisi Dan Moderniti, Syarahan Pengukuhan Profesor Untuk APIUM, 7 Hb Julai 2003, hh. 5-6.

49 Lihat sebagai contohnya, Rahimin Affandi Abdul Rahim (1995), "Budaya Taqlid Dalam Masyarakat Melayu : Satu Tinjauan Ringkas", dalam Jurnal Syariah, v. 3, bil. 1, hh. 29-41.

50 M.B. Hooker (1985), "The Translation Of Islam Into South-East Asia", dalam Readings On Islam In Southeast Asia. Singapore, hh. 11.

51 Omar Awang (1981), "The Major Arabic Sources Which Determined The Structure Of Islamic Thought In The Field Of Law, Theology and Sufism", dalam Islamika, v. 1, hh. 80-81; Fauzi Deraman, op.cit., hh. 493-502. 
tidak mempedulikan sumber rujukan yang asasi. ${ }^{52}$ Namun begitu, ini bukanlah bermakna fuqaha Melayu ini langsung tidak merujuk kepada sumber yang lebih asasi, Quran dan sunnah. Ini kerana kedapatan beberapa penerangan dalam kitab jawi karangan fuqaha Melayu yang merujuk dan memetik beberapa ayat Quran dan hadis sebagai landasan asas keterangan mereka.

4. Pedagogi pengajian adalah berbentuk banking concept di mana setiap kupasan guru akan dianggap sebagai final dan akan dihafal sepenuhnya oleh seseorang pelajar. Proses interaksi antara guru-pelajar adalah agak terbatas hanya membabitkan proses mengetahui huraian maksud sesuatu teks pengajian tanpa disertakan dengan penganalisaan kritikal oleh pihak pelajar. ${ }^{53}$

5. Guru ataupun fuqaha yang terlibat dalam pengajaran pengajian Syariah memang mengamalkan pendekatan aktif dalammenangani sesuatu isu yang timbul dalammasyarakat. ${ }^{54}$ Dalam beberapa kes terpencil, terdapat beberapa orang guru yang memberikan respon bernas yang bersalahan dengan pendapat mazhab Syafi'i sendiri. Hal ini secara langsung membuktikan bahawa fuqaha Melayu terbabit memang memahami sifat dinamisme sistem fiqh Islam dan berani mengkritik sesetengah pandangan daripada mazhab mereka sendiri. ${ }^{55}$

6. Mementingkan usaha dakwah yang praktikal melebihi kepentingan kebendaan. Hal ini boleh dilihat daripada

52 Rahimin Affandi Abd. Rahim (1994), "Reformasi Perundangan Islam Di Malaysia: Antara Impian Dan Realiti”, dalam Jurnal Syariah, v. 2, bil. 1, hh. 51-52.

53 Abdullah Alwi Haji Hassan (2003), op.cit., hh. 1-2.

54 Rahimin Affandi Abd Rahim (2005), “ Islam dan dialog peradaban: Konsep dan Idealism”, dalam Azizan Baharuddin (ed.) Islam dan Dailog Peradaban. Kuala Lumpur: Pusat Dailog Peradaban UM, hh. 2753.

55 Contohnya boleh dilihat dalam Azyumardi Azra (2004), Jaringan Ulama Timur Tengah Dan Kepulauan Nusantara Abad XV11 Dan XV11. Bandung : Mizan. 
kesucian niat ulama Melayu yang menjadikan tujuan utama penulisan kitab jawi adalah untuk menyebar luaskan maklumat lengkap dan betul tentang ajaran Islam, tanpa mempedulikan persoalan manafaat kebendaan (royalti) yang bakal diperolehi oleh seseorang pengarang, seperti mana halnya yang diperjuangkan oleh kalangan pengarang pada masa sekarang dengan konsep harta intelek. ${ }^{56}$ Untuk memperjelaskan keadaan ini kita boleh melihat kenyataan yang diberikan oleh A.H. John yang mengkaji kitab jawi di wilayah Patani;

"The authors of Kitab jawi were writing not for themselves but for the enlightenment and training of students. The aims were to simplify and to explain not to dazzle with intellectual precocity. We can learn much about the Islamic principles emphasized in these writings and study which commentaries and glosses were used as supports, but it is difficult to make assessments about the intellectual achievements of the Kitab Jawi authors from their works"

\section{Mazhab Syafi'i dalam Pengajian Syariah di Zaman Pasca}

\section{Kemerdekaan}

Dalam bahagian ini, tumpuan khusus hanya akan diberikan kepada tiga aspek; (i) penggunaan teks asas, (ii) pedagogi pengajian dan (iii) bentuk kajian ilmiah yang dihasilkan yang diamalkan oleh pengajian Syariah di beberapa IPTA/IPTS aliran Islam terpilih. Memanglah diakui, masih lagi ada beberapa institusi pendidikan tradisional di Malaysia yang menawarkan subjek pengajian Syariah, tetapi kewujudan institusi pendidikan jenis ini

56 Maklumat lanjut tentang persoalan ini boleh didapati dalam Norliza Mohamad (1999), Hakcipta Dari Aspek Teori Harta Intelek Menurut Perspektif Islam, Tesis Sarjana Akademi Pengajian Islam Universiti Malaya. 
boleh dikatakan sudah tidak relevan dan terkeluar daripada arus pengajian Syariah perdana. ${ }^{57}$

Sejurus selepas Malaysia mencapai kemerdekaan, kesungguhan masyarakat untuk mempelajari pengajian Syariah masih diteruskan membabitkan institusi pendidikan tradisiona ${ }^{58}$ dan hal ini turut disedari oleh pihak British. Subjek pengajian Syariah telah dimasukkan ke dalam pengajian undang-undang agama di Fakulti Undang-undang Universiti Malaya, yang diolah menggunakan perseptif barat. Hal ini secara langsung telah menimbulkan beberapa kesan negatif untuk memahami syariah Islam, seperti; $;^{59}$

1. Menonjolkan sifat dinamisme sistem perundangan British yang kononnya lebih berjiwa moden dan sesuai dengan masyarakat Malaysia yang merdeka.

2. Menyempitkan ruang lingkup undang-undang Islam kepada soal kekeluargaan dan peribadi.

3. Menonjolkan sifat undang-undang Islam sebagai undangundang agama yang ketinggalan zaman, kejam dan hanya sesuai untuk realiti masyarakat Timur Tengah.

Nisbah keterbatasan sistem dan metodologi pengajian Syariah di institusi pendidikan tradisional dan moden ini kemudiannya telah dikritik hebat oleh segolongan sarjana Melayu-Islam, yang mendapat semangat baru yang timbul daripada fenomena gerakan kebangkitan semula Islam di tahun 1970an-1990an. Apa yang menariknya, gesaan dan perjuangan NGO Islam ini telah diterima pakai oleh pihak kerajaan dengan melakukan proses reformasi

57 Sharifah Zaleha Syed Hassan (1993), "Authority And The Syariah Court: The Life And Work Of A Malaysian Kadi", dalam Jurnal Antropologi Dan Sosiologi, v. 20, hh. 146-147.

58 Rahimin Affandi Abd Rahim (1999), “ The Malay-Muslim Legal Educational Sistem During The Colonial Period", dalam The Journal Of Hamdard Islamicus. Pakistan, v. 22, hh. 18-31.

59 Lihat Ahmad Ibrahim (1980), Legal Education In Malaysia. Singapore. hh. 32-38. 
terhadap sistem pengajian syariah di IPTA Islam. ${ }^{60}$ Dengan tersebarnya pendekatan pengkopratan universiti, pihak kerajaan telah memberi mandat kepada setiap IPTA dan IPTS untuk melakukan reformasi di dalam pengajian Syariah. ${ }^{61}$

Bagi menghadapi cabaran ini, terdapat beberapa falsafah, konsep dan pendekatan yang digunakan oleh IPTA/IPTS aliran Islam bagi mengisi program reformasi. Ianya terdiri daripada petikan berikut; ${ }^{62}$

1. Semangat tajdid dan pendekatan yang mahukan perjuangan Islam dilakukan dengan kaedah blueprint lengkap dan tidak secara retorik semata-mata.

2. Memperkenalkan konsep dan dinamisme yang terdapat dalam pengajian Syariah, yang sekaligus cuba membetulkan tohmahan negatif yang kerap dinisbahkan kepada pengajian keilmuan Islam.

3. Menaja dan menyebarluaskan gagasan Fiqh semasa yang dicirikan dengan keperluan Malaysia semasa dan dianggap sebagai pemangkin utama ke arah mewujudkan masyarakat Malaysia yang membangun dalam kedua-dua aspek, material dan spiritual.

4. Melakukan proses integrasi antara subjek Islam dengan keilmuan moden.

5. Perubahan pedagogi pengajian Syariah bentuk baru yang berteraskan kepada keperluan semasa.

60 Rahimin Affandi Abd Rahim (1997), “ Gerakan Tajdid Di Malaysia: Teori Dan Realiti “, dalam Mahmood Zuhdi Hj. Ab. Majid (ed.), Dinamisme Pengajian Syariah. Kuala Lumpur, hh. 93-106.

61 Abdul Aziz Bari (1999), “ Legal Education And Islamization”, dalam IIUM Law Journal, v. 7, no. 1, hh. 83-94.

62 Rahimin Affandi Abd Rahim (2000), “Konsep Fiqh Malaysia Untuk Tamadun Alam Melayu Alaf Baru : Suatu Analisa Tentang Kepentingannya", dalam Jurnal Pengajian Melayu, bil.10; Rahimin Affandi Abd Rahim (2000) "Fiqh Malaysia: Suatu Tinjauan Sejarah", dalam Paizah Ismail (ed.), Fiqh Malaysia: Ke Arah Pembinaan Fiqh Tempatan Yang Terkini. Kuala Lumpur, hh. 39-40. 
6. Penerapan kerangka metodologi penyelidikan ilmiah baru mengantikan kerangka silam yang sudah ketinggalan zaman.

7. Melakukan proses penambahbaikian yang berterusan terhadap sesuatu program pengajian Syariah.

Secara kasarnya, di Malaysia terdapat dua jenis institusi pengajian; IPTA (mendapat bantuan dana kerajaan sepenuhnya) dan IPTS (bersifat independent dan tidak bergantung sepenuhnya kepada dana kerajaan). Terdapat 5 buah IPTA yang menawarkan bidang pengajian Syariah, manakala IPTS pula terdiri daripada 23 buah kesemuanya. 5 buah IPTA ini bertujuan melahirkan guna tenaga untuk sektor kerjaya secara langsung, memandangkan ianya mendapat pengiktirafan rasmi pihak kerajaan. IPTS pula lebih bersifat semi profesional, menekankan program sijil dan diploma, kurang mendapat pengiktirafan daripada sektor kerjaya dan lebih menumpukan kepada program berkembar bagi menyediakan pelajar untuk melanjutkan pengajian di beberapa buah universiti Timur Tengah. ${ }^{63}$ Selain itu juga, IPTS dikesan mempunyai pelbagai kelemahan seperti (i) kekurangan pasarana pengajian yang kondusif, (ii) tenaga pengajar yang kurang bermutu, (iii) nisbah pelajar yang mempunyai pencapaian akademik yang sederhana dan (iv) kurangnya pengiktirafan sektor kerjaya luar. Bagi memastikan kesemua IPTS ini memenuhi piawaian dan keperluan pendidikan negara, ianya telah diletakkan di bawah pengawasan LAN, suatu badan rasmi kerajaan bagi mengelakkan proses penipuan calon pelajar di jalankan oleh IPTS terbabit. ${ }^{64}$

63 Hasil dapatan kajian daripada projek penyelidikan bertajuk Kajian Impak Lulusan Universiti Al-Azhar Terhadap Pembangunan Sosial Di Malaysia, daripada dana penyelidikan Vote Fundamental UM 2005.

64 Tan Ai Mei (2002), Malaysian Private Higher Education : Globalisation, Privatisation, Transformation and Marketplaces. London. 


\section{Penggunaan Teks Asas dan Sumber Rujukan dalam Pengajian Syariah Semasa ${ }^{65}$}

Bagi subjek fiqh, bersesuaian dengan pendekatan fiqh semasa yang menuntut penggunaan kitab fiqh yang lebih terbuka, kita mendapati bahawa teks asas mazhab Syafi'i masih lagi dipakai secara meluas, tetapi kebanyakannya lebih menjurus kepada penggunaan teks moden dan bukannya kepada teks ataupun manuskrip klasik. Di samping itu juga, penggunaan kitab fiqh yang lebih terbuka daripada pelbagai mazhab telah turut dilaksanakan. Dalam pendekatan baru ini, kebanyakan pengajian Syariah telah menggunapakai sumber asas dari pelbagai mazhab dalam beberapa bentuk sebagaimana berikut;

- Kitab fiqh moden yang dihasilkan oleh fuqaha kontemporari yang membabitkan isu-isu semasa yang lebih praktikal.

- Ensklopedia hukum Islam moden yang membabitkan pelbagai isu semasa menggunakan pendekatan perbandingan antara semua mazhab terbesar dalam Islam.

- Koleksi fatwa moden yang membabitkan isu moden yang benar-benar berlaku di dalam masyarakat umat Islam semasa. Ianya bukan terhad kepada koleksi bertulis bahkan juga kepada koleksi dalam bentuk homepage.

- Statut dan enakmen undang-undang Islam Malaysia dari pelbagai negeri, termasuklah juga enakmen undang-undang Islam yang diamalkan di kebanyakan negara umat Islam antarabangsa.

Hal yang sama juga turut diterapkan untuk subjek Usul Fiqh yang membabitkan isu manhāj usūli ataupun metodologi usul Fiqh. Apa yang jelasnya, kebanyakan sistem pengajian syariah di Malaysia amat terbuka dan mendedahkan kepada pelajar kaedah

65 Maklumat ini diperolehi daripada pengalaman penulis sebagai ahli panel penilai LAN yang bertanggungjawab meneliti dan mengaudit dokumen rasmi dalam bidang pengajian Syariah yang disediakan oleh IPTA/IPTS aliran Islam di Malaysia. Setiap IPTS yang ingin mendapat perakuan akreditasi daripada LAN perlu menyediakan dokumen yang mengandungi semua perkara tentang kursus pengajian Syariah yang ditawarkan. 
usūli yang lebih luas, tanpa membataskannya kepada kaedah usuli mazhab Syafi'i semata-mata. Sebagai contoh, bahan sumber untuk subjek Usul Fiqh ini lebih menekankan kepada beberapa kaedah Usul Fiqh moden; kaedah ijtihàd tarjihi $\bar{i}$ dan insya ${ }^{\prime} \bar{i}$, teori maqāṣid Syariah, konsep maṣlahah, qawā'id fiqhiyyah, konsep fiqh awlawiyyah, konsep adat tempatan ('urf) Melayu, konsep siyāsah syariah dan prinsip rukhșah dan darurat.

\section{Pedagogi Pengajian Syariah ${ }^{66}$}

Merujuk khusus kepada isu pedagogi pengajian, tidak keterlaluan jika dikatakan bahawa sistem pengajian Syariah IPTA/IPTS semasa telah mencapai tahap positif yang boleh dibanggakan. Hal ini telah diakui sendiri oleh beberapa orang pengkaji dalam dan luar negeri. ${ }^{67}$ Pencapaian yang dimaksudkan antara lainnya merangkumi;

Pertama, penerapan paradigma pengajaran tajdid yang lebih bersifat interaktif. IPTA/IPTS masih menggunapakai bentuk pengajaran kuliah (satu hala) dan pendekatan tutorial (dua hala). Falsafah pedagogi pengajaran bentuk baru (islah - tidak menolak semua elemen tradisi) ini dirangka dengan mengubahsuai paradigma pendidikan tradisional, seperti;

- Pendekatan student-oriented menggantikan pendekatan teacher-oriented (banking concept). Kedua belah pihak iaitu guru dan pelajar perlu berinteraksi dalam konteks

${ }_{66}$ Maklumat ini diperolihi daripada projek penyelidikan pelajar di peringkat pasca siswazah yang menyentuh bidang pengajian syariah di pelbagai IPTA dan IPTS di Malaysia. Ianya terdiri dari Suraya Mohd Zain, Metodologi Pengajian Syariah di Kolej UNITI, Negeri Sembilan, pada sessi 2003/2004; Zurita Mohd Yusoff, Metodologi Pengajian Syariah di KUSZA, Terengganu, pada sessi 2003/2004; Hasnizam Bin Hashim, Metodologi Pengajian Syariah di Universiti Islam Antarabangsa Malaysia, pada sessi 2003/2004; Rosliza@ Rosli Mahmud, Metodologi Pengajian Syariah di Pondok Moden, Kandis, Bachok, Kelantan, pada sessi 2003/2004.

67 Lihat Akh. Minhaji (2003), Masa Depan Pembidangan Ilmu Di Perguruan Tinggi Agama Islam. Jogjakarta: Percetakan Ar-Ruzz Jogjakarta, hh. 62-80. 
yang lebih terbuka dan kritikal. Dalam soal ini, pendekatan pembelajaran yang berbentuk banking concept dan teacheroriented telah cuba dielakkan. Dalam pendekatan banking concept yang biasanya digunakan dalam paradigma taqlid, ianya menafikan kreativiti seseorang pelajar dalam mengupas sesuatu persoalan. Manakala paradigma teacheroriented pula merujuk kepada pendekatan yang terlalu bergantung sepenuhnya kepada guru sehingga melupakan peranan yang perlu dimainkan oleh seseorang pelajar. Lebih tepat lagi, pelajar perlu bertindak dengan lebih proaktif di dalam kajiannya dan menganggap gurunya hanya sebagai pembimbing dan fasilitator semata-mata. ${ }^{68}$

- Pendekatan yang menggalakkan pensyarah-pelajar menggunakan kemahiran ICT moden (virtual studies) seperti pencarian maklumat pengajian melalui laman web internet dan persembahan pengajaran-tutorial menggunakan peralatan ICT. ${ }^{69}$

Kedua, penerapan dua kaedah pedagogi baru iaitu kaedah PBL (Problem Based Learning) dan kaedah kemahiran berfikir dan berkomunikasi (bahasa Arab dan Inggeris) yang boleh menjanakan daya kritikal dan kebolehan menyelesaikan masalah semasa kepada pelajar. Berasaskan kepada laporan kelemahan pelajar IPTA semasa amnya dan IPTA Islam khususnya, yang dikatakan mempunyai kelemahan berfikir dan berkomunikasi yang betul, ${ }^{70}$ yang kemudiannya lulusan IPTA ini gagal memenuhi pasaran sasaran pekerjaan, maka pihak IPTA/IPTS telah mengambil

68 Abuddin Nata (2004), Sejarah Pendidikan Islam: Pada Periode Klasik Dan Pertengahan. Jakarta: Rajawali Press, hh. 20-22.

Nik Salida Suhaila Bt Nik Saleh \& Syahirah Bt Abdul Shukor (2004), "E-Learning In Islamic Studies: Possibilities And Challenges In Malaysia", dalam Prosiding Islam: Past, Present And Future-International Seminar On Islamic Thoughts, Anjuran Bersama Jabatan Usuluddin Dan Falsafah, UKM Dengan Jabatan Hal Ehwal Khas, Kementerian Penerangan Malaysia, pada 7-9hb. Disember 2004.

70 Untuk Maklumat Lanjut Sila Lihat Mohamad Mohsin Mohamad, "Kemahiran Berfikir Di Alaf Baru", dalam Abdul Latif Samian \& Mohamad Sabri Haron (eds.) Pengajian Umum Di Alaf Baru. hh. 195-204. 
inisiatif dengan memperkenalkan kaedah PBL ini. Kaedah ini yang biasanya dipakai untuk pelajar bidang perubatan, yang kononnya mampu melatih para pelajar menjadi pekerja yang boleh menganalisa setiap masalah yang timbul dalam bidang masingmasing serta menyertakan jalan penyelesaian masalah terbaik untuk masalah tersebut. ${ }^{71}$

Sebagai contohnya, kaedah PBL ini telah digunakan dalam subjek hukum Islam, yang memerlukan empat langkah yang utama;

1. Pelajar akan didedahkan dengan kerangka konsep dan senarai buku rujukan yang berautoriti untuk sesuatu subjek hukum yang diajar.

2. Pendedahan tentang senario sesuatu masalah Islam sebenar akan dibentangkan untuk diselesaikan secara berkumpulan oleh pelajar, contohnya seperti membabitkan sesuatu fatwa yang dikeluarkan oleh Jawatankuasa Fatwa Kebangsaan.

3. Pelajar perlu melakukan penyelidikan secara holistik terhadap sesuatu masalah yang diberikan, yang barang pastinya akan membabitkan pelbagai disiplin ilmu moden yang lain. Dalam soal ini, sebagai contohnya, pelajar terpaksa melihat latarbelakang realiti sebenar sesuatu masalah itu timbul danjuga perlu menganalisis secara kritikal kandungan fatwa yang dikeluarkan oleh JFK, samada ianya bersesuaian dengan prinsip Usul Fiqh, maqasid al-shariah dan realiti Malaysia.

4. Hasil penyelidikan pelajar ini akan dibentangkan di dalam kelas yang bakal dinilai oleh pelajar lain dan pensyarah itu sendiri.

Kaedah PBL ini bertepatan dengan tuntutan agenda pendidikan untuk dunia global semasa yang menghendaki pensyarah dan pelajar perlu berinteraksi dalam konteks yang lebih terbuka dan kritikal. Dalam sejarah pendidikan perundangan Islam, ternyata kaedah PBL ini walaupun diberikan dengan nama yang berbeza,

${ }^{71}$ Lihat Sebagai Contohnya Rahimin Affandi Abd. Rahim (2002), "Memperkasakan Budaya Berfikir Islam: Satu Analisa", dalam Jurnal Afkar, bil. 3. Kuala Lumpur: Universiti Malaya, hh. 57-80. 
sebenarnya pernah dijadikan metode utama di dalam pengajian Syariah yang awal. Hal ini boleh dilihat dengan kaedah mantik, hadali, istiqrā' $i$ dan tarjih dalam tradisi pengajian syariah silam. ${ }^{72}$

Jika dinilai dalam konteks penggunaan manhāj uṣuli mazhab Syafi'i, pemakaian kaedah PBL ini ternyata telah menyebabkan pensyarah-pelajar mengamalkan sikap yang lebih terbuka dan tidak terlalu bergantung secara rigid kepada manhaj usuli mazhab Syafi'i. Dalam soal ini beberapa perkara telah dikenalpasti iaitu;

- Pensyarah hanya membentangkan kaedah uṣuli mazhab Syafi'i secara teorikal semata-mata tanpa dikaitkan dengan aplikasi untuk realiti kehidupan semasa. Dengan cara ini, pensyarah hanya akan membentangkan kaedah ini untuk tujuan pengetahuan (transmisi ilmu) semata-mata kepada pelajar tanpa memperluaskannya kepada fakta isu yang timbul di dalam kehidupan sebenar.

- Pensyarah akan membentangkan kaedah ușuli mazhab Syafi'i serta mazhab lain untuk penyelesaian sesuatu masalah hukum yang timbul.

- Seandainya jawapan hukum dalam mazhab Syafi 'i samada dalam bentuk pendapat ( $Q \bar{a} w l \bar{i})$ ataupun manhaj gagal ditemui, tumpuan penyelesaian akan terus dirujuk kepada mazhab lain.

- Rujukan kepada manḥāj uṣuli dalam mazhab Syafi'i dibuat secara simplistik, dengan hanya merujuk kepada kaedah qiyas secara ringkas tanpa mengguna pakai kaedah ta'lil qiyās yang lebih mendalam. ${ }^{73} \mathrm{Hal}$ ini mendorong pensyarah/pelajar lebih suka merujuk terus kepada teori Maqasid Syariah dan konsep fiqh awlawiyyah yang dilihat lebih fleksibel untuk penyelesaian masalah hukum yang timbul.

72 Maklumat lanjut boleh didapati dalam Amir Mu'allim \& Yusdani (1999), Konfigurasi Pemikiran Hukum Islam. Yogyakarta: Pustaka Pelajar, hh. 31-33 \& 64-67.

73 Untuk maklumat yang baik tentang kaedah Ta'lil Qiyas secara mendalam ini, sila lihat Muhammad Firdaus Nurul Huda (1998), "Kesan Perubahan Sosial Terhadap Hukum Islam: Satu Kajian Tentang Metodologi Syariah Dan Pelaksanaannya", Tesis PhD, Jabatan Fiqh dan Usul, APIUM. 
Ketiga, menerapkan pendekatan yang lebih bersifat bersepadu dan integrasi antara ilmu Islam dan sekular. Secara positifnya, pendekatan ini memperkenalkan subjek yang menunjukkan perkaitan antara Islam dengan persoalan dan disiplin moden; merangkumi subjek ekonomi, pengurusan, perundangan, pentadbiran awam dan sebagainya. Subjek-subjek ini dapat membiasakan pelajar dengan subjek keilmuan moden yang biasa dipakai dalam realiti kehidupan semasa. ${ }^{74}$

Daripada pengamalan realiti pedagogi ini, kita dapat mengesan beberapa kelemahan;

1. Bentuk pengajian yang diamalkan kurang memberikan perincian tentang kaedah/manhạa ușuli mazhab Syafi'i, yang juga sepatutnya diterapkan secara integrated dalam bentuk aplikasi untuk realiti yang sebenar. Hal ini akan menyebabkan ilmu Usul Fiqh hanya dijadikan sebagai subjek sejarah hukum Islam (barang mati) semata-mata tanpa dikaitkan dengan realiti sebenar masyarakat. ${ }^{75}$

2. Pelajar gagal memperolehi kemahiran ilmu Usul Fiqh secara praktikal yang membolehkan mereka mempergunakannya apabila berhadapan dengan permasalahan hukum Islam yang timbul dalam masyarakat. Maknanya, pelajar terbabit tidak mampu menggunakan ilmu usul sebagai kaedah penyelidikan hukum Islam seperti yang sepatutnya dimiliki oleh seseorang pelajar di bidang pengajian Syariah. Dalam sejarah tradisi pengajian Syariah yang diamalkan oleh Madrasah Nizamiyyah, pengajaran ilmu Usul Fiqh telah mampu melahirkan graduan yang kompeten dalam profesion perundangan Islam, seperti mufti dan qadi. ${ }^{76}$

74 Lihat Idris Awang (1995), "Perkembangan Pengajian Di Fakulti Syariah Akademi Islam Universiti Malaya”, dalam Jurnal Syariah, v.3, bil. 2, hh. 301-307.

75 Hal ini telah ditegaskan oleh Mahmuud Zuhdi Abd Majid (2005) dalam Bengkel Kaedah Pengajaran Ilmu Usul Al-Fiqh, pada 16hb. Jun 2005, bertempat di Balai Ilmu, APIUM.

76 M. Akmansyah (2004), "Madrasah Nizhamiyyah", dalam H. Abuddin Nata (ed.), Sejarah Pendidikan Islam: Pada periode klasik dan pertengahan. Jakarta: PT Raja Grafindo Persada, hh. 62-66. 
3. Ianya bakal menyempitkan sifat fleksibiliti yang dimiliki oleh kaedah ușuli mazhab Syafi'i berbanding dengan mazhab lain. Sepatutnya, hal ini tidak boleh berlaku sedemikian rupa memandangkan Imam Syafi' $i$ merupakan tokoh pertama yang menyusun formula metodologi hukum Islam berpandukan; ${ }^{77}$ (i) hiraki sumber hukum wahyu dan ijtihad yang tersusun, (ii) kaedah pentafsiran nas yang sepatutnya dilakukan oleh seseorang fuqaha; (iii) kaedah ijtihad-qiyas yang ketat bagi memastikan agar setiap hasil ijtihad tidak bertentangan dengan nas wahyu; (iv) syarat mujtahid yang ketat dan (v) nisbah bidang yang diboleh dan tidak dibolehkan untuk dilakukan ijtihad. Tidak hairanlah seandainya terdapat sarjana barat yang menegaskan bahawa Imam Syafi'i yang bertanggungjawab meletakkan asas dan paradigma hukum Islam yang sebenarnya. Lagipun, proses pengembangan formula Usul Fiqh ini yang diteruskan oleh fuqaha terkemudian bertitik tolak kepada asas yang diletakkan oleh Imam Syafi' ${ }^{7}{ }^{78}$

4. Kelemahan penguasaan pelajar dalam bidang Usul Fiqh juga berkait rapat dengan sistem pengajian Syariah semasa yang terlalu umum sifatnya, seperti mana ditegaskan oleh Abdullah Alwi;

"Dalam sistem yang ada sekarang, penuntut telah dipolarisasikan ke arah penjurusan keilmuan sejak sekolah menengah lagi, dengan streaming terlalu awal. Sedangkan di peringkat ijazah pun tidak sepatutnya pengajian Islam itu terlalu pengkhususan, malahan sekarang terdapat pentakhasusan dalam takhassus, yang mengakibatkan pelajar terhambat dengan pengkhususan dan tercicir dari memahami pengajian Islam secara sejagat, tidak sepertipara ulamak terdahulu. ....Sepatutnya pentakhasusan hendaklah dilakukan di peringkat pengajian pasca siswazah. "79

77 Louay Safi (1998), Asas-Asas Ilmu Pengetahuan: Satu Kajian Perbandingan Kaedah-Kaedah Penyelidikan Islam Dan Barat, Nur Hadi Ihsan (terj.), Kuala Lumpur, hh. 39-74.

78 W. Hallaq (1992), "Usul al-Fiqh : Beyond Tradition”, dalam Journal Of Islamic Studies, v. 3(2), hh. 185-186.

79 Abdullah Alwi Haji Hassan (2003), op.cit., h. 11. 


\section{KAJIAN ILMIAH DALAM PENGAJIAN SYARIAH SEMASA}

Indek utama untuk mengukur ketinggian sesuatu tamadun manusia bukan hanya terletak kepada nisbah dan kuantiti besar sesuatu artifak kebendaan semata-mata. Apa yang lebih penting lagi, keunggulan elemen kebendaan ini perlu diiringi pula dengan kewujudan sejumlah besar golongan ilmuan yang bermutu dari segi akhlak, keterampilan diri dan keberkesanan teori serta aplikasi ilmu yang dihasilkan. Dalam soal ini, kita boleh menqiyaskannya dengan neraca utama yang biasanya digunakan untuk menilai kehebatan sesuatu institusi pendidikan tinggi; (i) kelengkapan kebendaan dan penyelidikan yang baik, (ii) jumlah mahasiswa yang genius dan mampu berdikari, (iii) kalangan profesor yang melahirkan pelbagai hasil penyelidikan yang bermutu dan boleh diaplikasikan secara berkesan oleh kalangan masyarakat dan (iv) peratusan siswazah yang meneruskan pengajian di peringkat ijazah lanjutan. ${ }^{80}$

Atas dasar inilah kebanyakan IPTA/IPTS aliran Islam amat menitikberatkan penghasilan kajian ilmiah yang bermutu tinggi samada di peringkat ijazah pertama dan lanjutan. Dalam soal ini, kita akan mendapati bagaimana skop dan tumpuan kajian latihan ilmiah lebih bersifat terbuka tanpa terikat dengan paradigma mazhab Syafi'i. Beberapa perkara positif telah dikenal pasti, seperti;

1. Kajian yang menganalisis teks Melayu-Islam klasik (Malay digest) yang berkaitan dengan persoalan hukum Islam. ${ }^{81}$

80 Zaini Ujang (1993), Universiti: Mendukung Tradisi Intelektual. Kuala Lumpur: Institut Kajian Dasar, hh. 81-83.

81 Allauwiyah Binti Jusoh, Analisis Teks Undang-Undang Kedah Berasaskan Perspektif Hukum Islam, Tesis Sarjana, Jabatan Fiqh Dan Usul, APIUM, sessi 2005/2006; Nurul Ilyana Muhd Adnan, Analisis Teks Kanun Johor 1789 Berasaskan Perspektif Hukum Islam, Tesis Sarjana, Jabatan Fiqh Dan Usul, APIUM, sessi 2005/2006; Mohd Nazri Bin Chik, Perkembangan Itqan al-Muluk Bi Ta'dil al-Suluk 1911 ditinjau dari aspek latarbelakang and pengaruhnya kepada pelaksanaan Undang-Undang Islam di Terengganu, Tesis Sarjana, Jabatan Fiqh Dan Usul, APIUM pada sessi 2005/2006. 
2. Kajian yang menilai pengamalan mazhab Syafi'i dalam pelbagai isu hukum Islam menggunakan pendekatan semasa. ${ }^{82}$

3. Kajian terhadap tema kajian yang agak mendesak keperluannya di kalangan umat Islam semasa. Antara isu-isu ini yang termasuk dalam subjek fiqh kepenggunaan adalah rawatan kumbahan air, ${ }^{83}$ sains perubatan ${ }^{84}$ Bio-perubatan, ${ }^{85}$ Farmasi, ${ }^{86}$ Astronomi, ${ }^{87}$ hasil tenusu $\mathrm{F} \& \mathrm{~N},{ }^{88}$ adat budaya Melayu $^{89}$ dan sebagainya.

82 Hasanah Binti Abd Khafidz (2006), Asnaf Lapan: Kesan Nilai Semasa Dan Setempat Dalam Menentukan Pentafsirannya Di Malaysia, Tesis Phd, Jabatan Fiqh Dan Usul, APIUM.

83 Nadzirah Ismail (2003), Status Kesucian Air Kumbahan Yang Dirawat Melalui Kaedah Rawatan Oleh Indah Water Konsortium, Tesis Sarjana, Jabatan Fiqh Dan Usul, APIUM.

84 Azhar Abdul Aziz (2002), Peranan Sains Perubatan Dalam Menentukan Hukum Keharusan Fasakh Kerana Penyakit, Tesis Sarjana, Jabatan Fiqh Dan Usul, APIUM.

85 Nizaita Omar (1999), Beberapa Kaedah Perubatan Moden Menurut Perspektif Islam, Tesis Sarjana, Jabatan Fiqh Dan Usul, APIUM.

86 Mohd Sharkawi Shaadan, Penggunaan Bahan Haram Dalam Perubatan: Kajian Di Pusat Perubatan Universiti Malaya, Kuala Lumpur, Tesis Sarjana Untuk Jabatan Fiqh Dan Usul, APIUM, 2003.

87 Mohamad Amin Abu Bakar (2002), Pemakaian Asas Astronomi Dalam Menentukan Arah Qiblat Di Malaysia: Satu Pendekatan Hukum, Tesis Sarjana, Jabatan Fiqh Dan Usul, APIUM.

88 Noor Asiah Binti Aling (2004), Barangan Tenusu Keluarga F\&N : Satu Kajian Berasaskan Hukum Kepenggunaan Islam, Tesis Sarjana, Jabatan Fiqh Dan Usul, APIUM.

89 Mohd Anuar Ramli (2002), Asas hukum dalam budaya: Kajian terhadap beberapa aspek hubungan sosial dalam kebudayaan Malaysia, Tesis sarjana, Jabatan Fiqh dan Usul, APIUM. 
4. Kajian yang membabitkan institusi keIslaman seperti institusi fatwa ${ }^{90}$ dan mahkamah Syariah. ${ }^{91}$

5. Kajian tentang kaedah reformasi pengeluaran zakat pertanian dan profesional bakal menyumbangkan idea tentang bagaimana institusi zakat ini boleh menjana perkembangan ekonomi umat Islam yang lebih baik

Di sebalik pencapaian positif seperti diterangkan di atas, kita dapat mengesan beberapa perkara;

1. Masih terdapat kelangkaan tumpuan kajian di mana manhaj usuli milik mazhab Syafi'i masih belum mendapat tumpuan yang memuaskan oleh pengkaji di Malaysia. ${ }^{92}$ Hal ini untuk jangka masa panjang bakal membantutkan proses penjanaan program pembangunan metodologi Usul Fiqh mazhab Syafi'i, ataupun sekurang-kurangnya gagal memberikan garis panduan tentang bagaimana metodologi/ manhāj uṣuli mazhab Syafíi sepatutnya dikaitkan dengan realiti masyarakat Malaysia. Seandainya hal ini gagal dihasilkan, proses pembentukan fiqh tempatan yang berasaskan kerangka manhāj ușuli mazhab Syafi' $i$ pasti akan menemui jalan buntu. Selain daripada bergantung dengan sumber kajian ilmiah daripada luar negara untuk pengetahuan tentang manhaj usuli mazhab Syafi' $i$, pengkaji Malaysia sendiri yang sepatutnya menerangkan tentang realiti sosiologi masyarakat Malaysia.

90 Noor Naemah Abd Rahman (2003), Fatwa Jemaah Ulamak Kelantan Tahun 1920an Hingga 1990an : Satu Analisis, Tesis Phd, Jabatan Fiqh Dan Usul, APIUM.

91 Ahmad Hidayat Buang (2005), Mahkamah Syariah di Malaysia. Kuala Lumpur: Jabatan Syariah dan Undang-undang, APIUM.

92 Setakat ini pemilihan tema ini amat terbatas sekali, merangkumi Muhammad Firdaus Nurul Huda (2002), Kesan Perubahan Sosial Terhadap Hukum Islam: Satu Kajian Tentang Metodologi Syariah Dan Pelaksanaannya. Kuala Lumpur: Thinker's Library; M. Hasbi Umar (2004), Pembaharuan Hukum Islam di Indonesia : Analisis terhadap 'illat al-Hukm dalam fatwa-fatwa Majlis Ulama Indonesia propinsi Jambi, tesis Ph.D, Jabatan Fiqh dan Usul, APIUM. 
2. Kajian yang berbentuk sosiologi hukum masih lagi berkurangan. Kajian bentukiniamatpentingbagimemastikan keseimbangan di antara idealism yang terkandung dalam hukum Islam dengan realiti perlaksanaannya di dalam masyarakat (law in action). ${ }^{93}$ Ianya bakal memperincikan elemen kelemahan yang dimiliki oleh institusi tersebut, yang perlu disedari dan dirangka jalan penyelesaian masalah yang terbaik.

\section{CADANGAN KE ARAH KELANGSUNGAN MAZHAB SYAFI'I DI DALAM PENGAJIAN SYARIAH DI MALAYSIA}

Sebagai langkah proaktif, dicadangkan beberapa langkah yang perlu diusahakan oleh pengajian Syariah semasa bagi memastikan kelangsungan mazhab Syafi' $i$ dapat diteruskan. Ianya terdiri daripada;

Pertama, walaupun mengamalkan pendekatan yang terbuka kepada semua mazhab, kita perlu memperhalusi dan mendalami warisan manhaj (metodologi) Usul Fiqh Imam Syafi'i. Hal ini boleh dilakukan dengan menggunakan pendekatan filosofis. Berasaskan kepada pengalaman pengajian Syariah di barat, ${ }^{94}$ kelebihan pendekatan ini untuk bidang pengajian Syariah boleh dirujuk kepada tiga perkara yang utama - (i) perumusan idea atau gagasan yang bersifat mendasar (fundamental ideas) dalam berbagai persoalan; (ii) keberanian menggunakan pemikiran kritis dan (iii) proses ini bakal membentuk mentaliti dan kaedah berfikir yang mengutamakan kebebasan intelektual, sekaligus mempunyai sifat toleran terhadap pelbagai pandangan yang berbeza serta bebas daripada fanatisme. ${ }^{95}$

93 Amir Mu'allim \& Yusdani (1999), Konfigurasi Pemikiran Hukum Islam. Yogyakarta, hh. 46-47.

94 Rahimin Affandi Abd Rahim (2005), “Isu Pendekatan di dalam Pengajian Syariah di Malaysia: Satu Telaah Awal”, dalam Jurnal Syariah, v. 13, bil. 1, hh. 105-134.

95 Kamaruzzaman Bustaman Ahmad (2002), op.cit., hh. 9-10. 
Berasaskan kepada pendekatan ini, kita perlu memperincikan metodologi (manhāaj uṣuli) berasaskan sumber naqli dan aqli terhadap permasalahan hukum amali yang timbul di dalam masyarakat, yang diasaskan oleh mazhab Syafi'i. Antara kaedah yang kerap diguna pakai oleh fuqaha terdiri dari ${ }^{96}$ :

- Kaedah deduktif (istinbat) yang memetik kesimpulan khusus dari dalil-dalil umum yang terkandung di dalam sumber Naqli.

- Kaedah induktif (istiqra'i) yang memetik kesimpulan hukum umum yang dihasilkan dari fakta-fakta khusus, terutamanya terhadap sesuatu masalah yang tiada ketentuan nasnya daripada Quran dan sunnah.

- Kaedah pensejarahan (takwini) yang meneliti latar belakang yang menyebabkan munculnya sesuatu nas syarak (Quran dan sunnah) di dalam masalah hukum. Ia menumpukan perhatian terhadap dua perkara utama, pertamanya, sebabsebab kemunculan sesuatu masalah hukum yang telah diselesaikan oleh nas naqli (asbāb nuzūl) dan keduanya kualiti periwayatan nas syarak tersebut (asbāb wurūd).

- Kaedah perbincangan dialektik (jadali) yang memetik kesimpulan hukum menggunakan pemikiran berasaskan prinsip-prinsip logik terhadap pertanyaan dan pernyataan yang bersifat tesis dan antitesis. Kaedah ini yang biasanya menggunakan tiga sub kaedah ijtihad, iaitu Ijtihad Bayani, ta'lili dan istislahi $\bar{i}$ telah menghasilkan sebahagian besar perbendaharaan sistem fiqh Islam. ${ }^{97}$

Kedua, mengamalkan sikap positif dan selektif yang bertapis terhadap gagasan bermazhab. Dalam sejarah Alam Melayu, kita dapat menyaksikan bagaimana sikap taksub mazhab dan anti keterbukaan pandangan telah menyumbang kepada wujudnya serangkaian penindasan terhadap golongan sesama Islam, seperti dalam kes pertentangan antara Hamzah Fansuri dan Nuruddin al-Raniri. ${ }^{98}$ Secara tidak langsung hal ini telah mencacatkan citra

\footnotetext{
96 Maklumat lanjut boleh didapati dalam Amir Mu'allim \& Yusdani (1999), op.cit., hh. 31-33.

97 Ibid., hh. 64-67.

98 Kamaruzzaman Bustaman Ahmad (2002), op.cit., hh. 259-264.
} 
tolenrasi dan perdamaian yang dinisbahkan kepada penganut Islam Alam Melayu. ${ }^{99}$

Ketiga, memahami disiplin Usul Fiqh ini bukan sebagai ilmu yang statik, tertutup dan telahpun disempurnakan oleh fuqaha silam yang mustahil untuk ditokok tambah oleh fuqaha yang terkemudian. Sebagai suatu disiplin ilmu, ianya perlu sentiasa berkembang mengikut peredaran zaman. Ringkasnya, bersesuaian dengan konsep ilmu itu sendiri, yang boleh diujikaji, dinilai kembali dan diperkemaskan oleh sarjana di dalam zaman yang berbeza, hal yang sama perlu diterapkan kepada disiplin Usul Fiqh ini. ${ }^{100}$ Contoh yang mendukung pandangan ini boleh dilihat daripada perbincangan fuqaha silam sendiri, yang bermula dengan teori Amal penduduk Madinah (dibawa oleh Imam Malik), teori $R a^{\prime} y$ (dibawa oleh Imam Abū Hanifah), teori Ijtihad-Qiyas (Imam Syafi ‘i), teori maslahah (dibawa oleh Shātibi) dan banyak lagi teori lain tentang pendekatan di dalam Usul Fiqh yang dikemukakan oleh fuqaha Islam sepanjang zaman. ${ }^{101}$ Kesemua teori-teori ini menunjukkan bagaimana fuqaha Islam memahami tentang sifat kesemasaan disiplin Usul Fiqh ini yang mengalakkan dan mengakui faktor penggunaan daya artikulasi dan intelektualisme seseorang fuqaha di dalam menghadapi masalah kehidupan sezaman. Walaupun teori-teori baru di dalam disiplin usul fiqh ini sentiasa berkembang, tetapi fungsinya adalah sama iaitu untuk menterjemah wahyu Allah (paradigma tekstual) bagi menjawab persoalan hukum yang timbul di dalam masyarakat (paradigma kontekstual).

Keempat, memasukkan dalam kurikulum pengajian Syariah semua pandangan dan teori terbaharu yang menyentuh tentang ilmu Usul Fiqh ini yang dikemukakan oleh pemikir dan fuqaha Islam

99 Azyumardi Azra, Renaisans Islam Asia Tenggara : Sejarah wacana dan kekuasaan, Bandung: PT Remaja Rosdakarya, , hlm xv-xvi.

100 Maklumat lanjut boleh didapati dalam Rahimin Affandi Abd. Rahim (2002), "Epistemologi Hukum Islam: Satu Pengenalan", dalam Jurnal Usuluddin, bil. 15.

101 Akh Minhaji (2002), "Persoalan Gender Dalam Persepktif Metodologi Studi Hukum Islam", dalam Siti Ruhaini Dzuhayatin (ed.) Rekonstruksi Metodologis Wacana Kesetaraan Gender Dalam Islam. Yogyakarta: Pustaka Pelajar Offset, hh. 200-206. 
terkini. Hal ini bakal menimbulkan sikap proaktif dan keberanian dalam kalangan pelajar pengajian Syariah tentang bentuk reformasi yang boleh dan telahpun cuba diterapkan kepada ilmu Usul Fiqh, yang seterusnya memerlukan pengkajian, penjanaan dan pengembangan mana-mana teori baru yang difikirkan sesuai untuk memperkasakan lagi disiplin ini. Antara teori-teori ini adalah seperti teori al-turath wa al-tajdid oleh Hassan Hanafi ${ }^{102}$, teori takwil dan tadwin oleh Nasr Hamid Abu Zayd, ${ }^{103}$ teori logosentrisme oleh Muhammad Arkoun ${ }^{104}$, teori hudud (batas) oleh Muhammad Syahrur ${ }^{105}$ dan teori model pemikiran bayani, burhani dan irfani oleh al-Jabiri. ${ }^{106}$ Walaupun diakui tidak semua daripada teori-teori ini sesuai dipakai untuk konteks Malaysia, tetapi sekurang-kurangnya ianya bakal menunjukkan tentang sifat kelewusan dan dinamisme yang terdapat di dalam pemikiran hukum Islam semasa. ${ }^{107}$

Kelima, memperjelaskan tentang aspek epistemologi hukum Islam dalam proses tajdid perundangan. Dalam sesuatu kajian ilmiah, terdapat suatu pendekatan yang menetapkan bahawa proses pengkajian yang mendalam terhadap sesuatu hakikat ilmu ataupun disiplin tertentu perlu dilihat kepada aspek epistemologi disiplin tersebut. ${ }^{108}$ Hal ini bersesuaian dengan takrif dan ruang lingkup epistemologi yang menyelidik asal usul, sumber, sifat,

102 Hassan Hanafī (1981), Dirāsah al-Islāmiyyah. Kaherah: Maktabah al-Mișriyyah.

103 Nasr Hamid Abū Zayd (1994), Mafhūm Al-Naṣs: Dirāsah Fī 'Ulūm Al-Qur'àn. Beirut: Markaz al-Saqafī al-'Arabì,

104 Muhammad Arkoun (1994), Rethinking Islam : Common Question, Uncommon Answers. Boulder: Westview Press.

105 Muhammad Shahrūr (1992), Al-Kitāb Wa Al-Qur'ān: Qira'āh AlMu ‘ạsirah. Kaherah: Șina li al-Nasr.

106 Muhammad 'Abid al-Jabirì (1989), Takwin al- 'Aql al- 'Arabi. Beirut: Markaz Dirāsah al-Widah al-'Arabiyyah, .

107 Wael Hallaq (1997), A History Of Islamic Legal Theory : An Introduction To Sunni Usul Al-Fiqh. Cambridge: Cambridge University Press, hh. 245-253.

108 Fadzulullah Hj. Shuib (1995), Kecermelangan Ilmu Dalam Sejarah Dan Tamadun Islam, Kuala Lumpur, hlm 33. 
kaedah dan had sesuatu ilmu tersebut. ${ }^{109}$ Dalam menghadapi cabaran zaman moden ini, sepatutnya sesuatu pengajian Syariah yang diusahakan perlu menitikberatkan persoalan epistemologi hukum Islam yang bakal memberikan gambaran yang jelas kepada penganut Islam dan bukan Islam tentang bagaimana Syariah Islam itu bukannya didasarkan kepada kepercayaan dogmatik yang tidak boleh dipertikaikan, tetapi ianya dibina atas dasar yang empirikal, rasional dan mempunyai sumber, sebab musabab dan kaedah yang rapi, sebelum menetapkan sesuatu hukum yang berkaitan dengan persoalan kemanusiaan. ${ }^{110}$

Ianya termasuk juga perlu memperkembangkan elemen ontologi, epistemologi dan aksiologi disiplin usul fiqh dengan perkiraan dan keilmuan semasa. ${ }^{11}$ Dengan mengambilkira tiga prinsip utama yang sering ditekankan penggunaannya dalam gagasan fiqh semasa iaitu urf, maslahah dan ilmu sains sosial moden, ternyata sekali usaha untuk memperkemaskan elemen epistemologi (sumber dan metode) Usul Fiqh adalah amat mendesak sekali. Hal ini dapat dilakukan dengan tiga pendekatan yang utama;

- Menggabungkan (sintesis) di antara ilmu Usul Fiqh ini dengan keilmuan moden lain (seperti ilmu sains sosial moden) yang sekaligus bakal melengkapkan lagi kaedah penyelidikan hukum Islam alternatif untuk zaman moden ini. ${ }^{112}$ Walaupun diakui ilmu Usul Fiqh ini memang hebat

109 Lihat sebagai contohnya kupasan yang dibuat oleh Muhammad Zainiy Uthman (2001), "Islam, Sains Dan Pemikiran Objektif: Suatu Perbandingan Ringkas”, dalam Jurnal YADIM, bil. 2, November 2001, hh. 146-148.

110 Harun Nasution (1989), Islam Rasional: Gagasan Dan Pemikiran. Jakarta, hh. 328-334.

111 Ainurrafiq Dawam (2004), “Menawarkan Epistemology Jama'i Sebagai Epistemology Usul Al-Fiqh: Sebuah Tinjauan Filosofis", dalam Riyanto (ed.), Neo Usul Fiqh : Menuju Ijtihad Kontekstual. Yogyakarta: Fakultas Syariah Press, hh. 1-23.

112 Rahimin Affandi Abdul Rahim (2003), "Pengajian Sosial Dan Hubungannya Dengan Pembinaan Hukum Islam Semasa: Satu Analisa”, dalam Isu-isu Sains Sosial dari perspektif Islam, Rahminah Muharam (ed.). Kota Kinabalu: Universiti Malaysia Sabah, hh. 1-34. 
dan berteraskan world-view Islam sepenuhnya, tetapi untuk konteks zaman moden ini ianya tidak boleh berdiri sendiri dan perlu disokong serta digabungkan dengan disiplin keilmuan lain.

- Membangunkan kaedah uruf Malaysia yang berbeza dengan uruf Timur Tengah, dari segi kerangka konsepnya dan kaedah aplikasi yang lebih sesuai dengan realiti Malaysia semasa. ${ }^{113}$

- Membangunkan prinsip dan standard maslahah dalam tiga jenis, khususnya maslahah daruriyyah, hajjiyyah dan tahsiniyyah yang lebih sesuai dengan realiti Malaysia semasa. Sebagai contohnya, seperti mana diusahakan oleh Ahmad Ibrahim yang cuba menghapuskan pemakaian English Common Law warisan penjajah British di Malaysia dan digantikan dengan pemakaian Malaysia Common law; sarjana hukum Islam Malaysia perlu menunjuk dan membangunkan secara pasti dari segi konsep dan aplikasinya Malaysia Common law ini - yang boleh dilakukan dengan berteraskan konsep uruf dan maslahah ala Malaysia.

Keenam, perlu berwaspada dengan gerakan Wahabism yang sedang giat berkembang menyebarkan pengaruhnya di beberapa IPTA/IPTS Islam. Ia menyebarkan seruan supaya tidak bermazhab yang dikesan turut mengunapakai pendekatan kekerasan dan menimbulkan isu-isu kontroversial. Gerakan ini dijangka gagal berkembang kerana beberapa faktor yang utama; i) Ianya bertentangan dengan world-view masyarakat Melayu yang menentang sebarang idea ataupun fahaman yang menjurus kepada kaedah kekerasan dan mencabar warisan turun temurun Melayu. ${ }^{114}$ ii) Gerakan ini sendiri tidak mempunyai metodologi (manhāj uṣuli) yang jelas, sebaliknya dilihat terlalu terikat dengan mazhab

113 Lihat sebagai contohnya tesis sarjana yang cuba mengupas tentang isu ini, yang dilakukan oleh Noor Haslina Binti Osman (2003), “ Adat Melayu Sebagai Sumber Hukum: Penilaian Dari Perspektif Teori Al'Urf Wa Al-Adah', Tesis sarjana, Jabatan Fiqh dan Usul, APIUM.

114 Maklumat lanjut boleh didapati dalam Noriati A. Rashid (2005), "Konsep Kesantunan Dalam Masyarakat Melayu", dalam Jurnal Antarabangsa Dunia Melayu, v. 3, bil. 1, Jun 2005, hh. 112-128. 
Wahabism yang diamalkan di Arab Saudi. Tindakan bermazhab yang dikritik hebat oleh golongan ini sekurang-kurangnya mampu menyediakan paradigma dan metodologi usuli syariah yang jelas dan applicable untuk zaman moden ini, sedangkan gerakan ini tidak mempunyai metodologi seumpamanya. ${ }^{15}$ iii) Ianya dilihat tidak dapat menjana pemikiran yang sihat kerana lebih suka menilai segala perkara termasuklah soal budaya Melayu menggunakan pendekatan legal formalistik (hitam putih), tanpa mengambilkira soal falsafah dan latar belakang sejarah yang terkandung di dalamnya. iv) Masyarakat lebih disibukkan dengan isu-isu furu' yang remeh, sedangkan masih ada lagi isu lain yang penting untuk ditonjolkan seperti perpaduan dan perpecahan sesama umat Islam. v) Sifat eksklusif (tertutup) dan pendekatan self truth claim menyebabkan ianya kurang dapat didekati oleh kalangan pengkaji daripada luar, apatah lagi hendak mengadakan intellectual discourse, memandangkan hanya pandangan mereka sahaja yang dianggap sebagai paling betul dan menafikannya kepada pihak lain. ${ }^{116}$

\section{KESIMPULAN}

Sebagai rumusan akhir, tidak keterlaluan jika dikatakan bahawa tindakan berpegang kepada sesuatu mazhab untuk amalan umat Islam seharian amnya dan pengajian Syariah khususnya bukanlah sesuatu tindakan yang salah. Ianya perlu difahami dalam konteks yang lebih luas dengan memahami falsafah sebenar amalan bermazhab ditetapkan oleh para sarjana Islam. Selama mana ianya bertepatan dengan world-view tauhid dan tidak mendorong seseorang itu terjerumus ke dalam semangat fanatik bermazhab, paradigma bermazhab ini boleh dianggap sebagai sesuatu yang

115 Pandangan ini dikeluarkan oleh Fazlur Rahman (1979) "Islam : Challenges And Opportunities", dalam Alford T. Welch (ed.), Islam: Past Influence And Present Challenge. Edinburgh: Edinburgh University Press, hh. 315-330.

116 Sebagai Maklumat Lanjut tentang gerakan Wahabism, Sila lihat Khaled M. Abou El-Fadl (2001), Atas Nama Tuhan: Dari Fikih Otoriter Ke Fikih Otoritatif, R. Cecep Lukman Yasin (terj.). Jakarta: PT Serambi Ilmu Semesta, hh. vii-xvii. 
lumrah kerana ianya dilakukan berasaskan kepada formula fuqaha Islam. Dilihat kepada amalan berpegang kepada mazhab Syafi‘i dalam pengajian Syariah di Malaysia, kita dapat mengesan elemen positif dan juga negatif sekaligus. Elemen positifnya, boleh disaksikan daripada sifat terbukaan pengajian Syariah dengan pendekatan tajdid yang sanggup menjadikan pandangan mazhab lain bersama dengan mazhab Syafi'i sebagai alat dan bahan kurikulum pengajian. Manakala elemen negatifnya pula, pengajian Syariah lebih terdedah kepada pendekatan simplistik apabila membabitkan penerangan terhadap manhaj usuli mazhab Syafi' $i$. Hal ini seandainya tidak ditanggani dengan berhemah akan menjejaskan nisbah penguasaan dan kelangsungan mazhab Syafi‘i di Malaysia. 